Harmonisasi Hukum Pengangkatan Anak Dalam Desa Adat Di Bali (Suatu Kajian Pluralisme Hukum) .......................... (NK. Kantriani \& IBS.Putra., 172-182)

\title{
HARMONISASI HUKUM PENGANGKATAN ANAK DALAM DESA ADAT DI BALI (SUATU KAJIAN PLURALISME HUKUM)
}

Oleh:

Ni Ketut Kantriani1 ; Ida Bagus Sudarma Putra²

E-mail: ketutkantriani@gmail.com¹; sudarmaputra@gmail.com²

Dosen Jurusan Hukum UHN I Gusti Bagus Sugriwa Denpasar

\begin{abstract}
Offspring is expected in marriage, in Hinduism the purpose of marriage, namely in the book of Manawa Dharmasastra, mentioned that praja (giving birth to offspring). But in reality in marriage not all the wishes that are expected will be achieved. In Bali marriages that do not have children generally perform the rapture of children. According to Balinese customary law the removal of children is generally a child who is raised from the purusha line (from the male lineage), the purpose of the child's rapture is to continue the offspring, responsibility in the form of rights and obligations. The appointment of children for a Hindu married couple who are Balinese, Then the implementation of the child appointment process should follow the provisions of Hindu law, then Balinese customary law (awig-awig and pararem) that applies in each customary village in addition to also still referring to the process of child adoption procedures that have been regulated in the applicable legislation in Indonesia. Based on this background, the issues discussed can be formulated as follows: 1. How to regulate the shahnya rapture of children according to customary law, Hinduism and National Law. 2. How the process of carrying out the appointment of children in indigenous villages in Bali is studied from legal pluralism. concepts: harmonization of law, adoption of children, pluralism of law, theory using legal pluralism (John Griffiths) and living law theory (Eugene Ehrlich), type of empirical legal research, descriptive nature of research, type of data qualitative and sourced from primary data and secondary data, using methods of data collection, obsenvation, interview, and literature. Determination of informants using non probability sampling, the instrument used by mobile phones, management and qualitative and systematic descriptive analysis. The results of research 1) The regulation of the shahnya child appointment can be seen from 3 legal bases, namely national law, customary law, and religious law. 2) In the process of carrying out the adoption of children in indigenous villages in Bali on the point of view of legal pluralism, namely the combination of three basic legal rules, including national law, customary law (awig-awig and pararem), and religious law (Hindu law), where the three legal bases run simultaneously in the implementation of child adoption in harmony, and balance, so as to create a harmony of law in the implementation of child appointment in indigenous villages in Bali
\end{abstract}

Keywords: Harmonization of the Law, Adoption of the Child, Pluralism of Law

\begin{abstract}
Abstrak
Keturunan merupakan hal yang diharapkan dalam perkawinan, dalam agama Hindu tujuan perkawinan, yaitu dalam kitab Manawa Dharmasastra, disebutkan yaitu praja (melahirkan keturunan). Akan tetapi dalam kenyataannya dalam perkawinan tidak semua harapan yang diingitkan akan tercapai. di Bali perkawinan yang tidak memiliki keturunan pada umumnya melakukan pengangkatan anak. menurut hukum adat Bali pengangkatan anak secara umumnya anak yang diangkat berasal dari garis purusha (dari garis keturunan laki-laki), tujuan pengangkatan anak adalah
\end{abstract}


untuk melanjutkan keturunan, tanggung jawab berupa hak dan kewajiban. Pengangkatan anak bagi pasangan suami istri yang beragama Hindu yang merupakan orang Bali, maka pelaksanaan proses pengangkatan anak patut mengikuti ketentuan hukum Hindu, kemudian hukum adat Bali (awig-awig dan pararem) yang berlaku di masing-masing desa adat selain itu juga tetap mengacu pada proses tata cara pengangkatan anak yang telah diatur dalam perundangundangan yang berlaku di Indonesia. Berdasarkan latar belakang tersebut maka masalah yang dibahas dapat dirumuskan sebagai berikut: 1. Bagaimana pengaturan terhadap syahnya pengangkatan anak menurut hukum adat, agama Hindu dan Hukum Nasional. 2. Bagaimana proses pelaksanaan pengangkatan anak dalam desa adat di Bali dikaji dari pluralisme hukum. konsep: harmonisasi hukum, pengangkatan anak, pluralisme hukum, teori yang gunakan pluralisme hukum (John Griffiths) dan teori living law (Eugene Ehrlich), jenis penelitian hukum empiris, sifat penelitiany deskriptif, jenis datanya kualitatif dan bersumber dari data primer dan data sekunder, dengan menggunakan metode pengumpulan data, obsenvasi, wawancara, dan kepustakaan. penentuan informan menggunakan Non probability sampling, instrument yang digunakan Handphone, pengolaan dan analisis deskriptif kualitatif dan sistematis. Hasil penelitian 1) Pengaturan terhadap syahnya pengangkatan anak dapat dilihat dari 3 dasar hukum yaitu hukum nasional, hukum adat, dan hukum agama. 2) Dalam proses pelaksanaan pengangkatan anak dalam desa adat di Bali pada sudut pandang pluralisme hukum yaitu adanya perpaduan antara tiga aturan dasar hukum antara lain hukum nasional, hukum adat (awig-awig dan pararem), dan hukum agama (hukum Hindu), dimana ketiga dasar hukum tersebut berjalan secara bersamaan dalam pelaksanaan pengangkatan anak secara selaras serasi, dan seimbangan, sehingga terciptanya suatu kerharmonisasian hukum dalam pelaksanaan pengangkatan anak dalam desa adat di Bali.

Kata Kunci : Harmonisasi Hukum, Pengangkatan Anak, Pluralisme Hukum

\section{PENDAHULUAN}

Kedudukan hukum adat keluarga di Bali dengan saat ini masih dikatakan kuat, hal tersebut dapat dilihat dalam kehidupan masyarakatnya masih ditaati khususnya pada aspek-aspek hukum yang terkait dengan ruang lingkup hukum keluarga seperti halnya yang diatur oleh Undang-undang Nomor 1 Tahun 1974 tentang perkawinan.

Pasal 1 dalam Undang-undang No. 1 Tahun 1974 disebut bahwa tujuan dari perkawinan adalah untuk membentuk keluarga bahagia serta kekal berdasarkan ketuhanan yang Maha Esa. Sedangkan dalam ajaran agama hindu selain bertujuan mendapatkan keturunan juga makardi rahayu kayang riwekasan ( membentuk keluarga yang sejatera ) .
Perkawinan Hukum adat di Bali tidak hanya peristiwa penting bagi orang yang melakukan perkawinan saja, akan tetapi terkait juga terhadap hal yang menyakut pada leluhur serta keluarga besar baik dari laki-laki ataupun perempuan. bagi yang beragama Hindu di Bali menganut sistem kekeluargaan Patrilineal, mengingat indikator tercapainya kedamaian dalam kehidupan perkawinan ialah kehadiran anak/keturunan.

Soerojo Wignjodipuro yang mengutip pengertian keturunan dari Djojodigoeno adalah sebagai berikut :

"Keturunan adalah ketunggalan leluhur artinya ada perhubungan darah antara orang yang seorang dengan orang lain. Dua orang atau lebih yang mempunyai hubungan darah. Jadi 
Harmonisasi Hukum Pengangkatan Anak Dalam Desa Adat Di Bali (Suatu Kajian

yang tunggal leluhur adalah keturunan yang seorang dari yang lain."

Selanjutnya Mudaris Zaini berpendapat bahwa naluri manusia adalah salah satunya ingin memiliki anak, hal tersebut sejalan dengan pembawaan watak kodrati manusia yang merasakan bahwa anak bagian dari darah daging orang tua yang juga akan mewarisi pula sifat-sifat istimewa dari kedua orang tuanya.

Akan tetapi dalam kenyataannya dalam suatu perkawinan tidak semua mencapai harapan serta tujuan yang dihendaki yaitu memiliki keturunan, maka tidaklah sedikit seseorang yang tidak memiliki keturunan memilih untuk melakukan pengangkatan anak. Pelaksanaan pengangkatan anak pada setiap daerah di Indonesia sangatlah berbeda-beda hal tersebut disesuai oleh hukum adat dan tradisi yang berlaku pada daerah setiap daerah. Khususnya hukum adat Bali secara umum anak yang diangkat berasal dari garis purusha sesuai dengan sistem kekeluargaan yang dianut di Bali yaitu sistem kekeluargaan Patrilineal, tujuan dilakukannya pengangkatan anak yaitu untuk melanjutkan keturunan dan sekaligus tanggung jawab baik hak maupun kewajiban terhadap keluarga dan tanggung jawab kepada masyarakat (desa adat).

Melihat dari penganturan terhadap pengangkatan anak di Indonesia begitu banyak mulai dari Undang-undang No 4 Tahun 1979 Tentang Kesejahteraan Anak, UU No.23 tahun 2002 Tentang Perlindungan Anak yang telah di amandemen dengan UU No 35 tahun 2014 Tentang Perlindungan Anak, Peraturan Pemerintah No. 54 tahun 2007 Tentang Pelaksanaan Pengangkatan Anak, Peraturan Menteri Sosial Republik Indonesia Nomor: 110 /Huk /2009 Tentang Persyaratan Pengangkatan Anak,
Peraturan Jenderal Rehabilitasi Sosial Nomor 02 Tahun 2012 tentang Pedoman Teknis Prosedur Pengangkatan Anak. Selanjutnya pengangkatan anak berdasarkan hukum adat dalam daerah tertentu secara satu perkumpulan yang nyatanyata masih melaksanakan tradisi dan kebiasa-kebiasaan dalam kehidupan bermasyarakat (Pasal 9 ayat (1) PP 54/2007), Khususnya hukum adat Bali secara umum pengangkatan anak tidak bias terlepas dari aturan adat Bali yang lebih banyak bernafaskan ajaran agama Hindu.

Melihat dari banyaknya aturan terhadap pengangkatan anak baik dari hukum nasional, hukum adat, atau hukum agama maka khususnya pengangkatan anak pada desa adat di Bali dalam awig-awignya buat suatu upaya penyelarasan peraturan nasional kedalam aturan adatanya mengenai pengangkatan anak supaya tidak menimbulkan ketidak harmonisan. Pada awig-awignya terhadap tata cara dan syarat kepada calon orang tua angkat tersebut beberapanya diadopsi dari aturan nasional seperti memiliki agama yang sama pada anak yang akan di angkat, berstatus menikah secara sah paling singkat 5 (lima) tahun, yang belum memiliki anak atau hanya memiliki satu anak, telah melakukan pengasuhan calon anak yang diangkat sekurang-kurang 6 (enam) bulan, mulai izin pengasuhan diberikan. Hal ini dapat dikatakan sebagai harmonisasi hukum terhadap upaya untuk menyelaraskan peraturanperaturan yang mengatur terhadap pengangkatan anak kedalam awigawignya.

Berdasarkan latar belakang tersebut di atas, maka masalah yang akan dibahas dapat dirumuskan sebagai berikut :

1. Bagaimana pengaturan terhadap Syahnya pengangkatan anak menurut hukum adat di Bali ? 
2. Bagaimana proses pelaksanaan pengangkatan anak pada desa adat di Bali dikaji dari sudut pandang plurarisme hukum ?

\section{METODE}

Penelitian ini menggunakan metode penelitian hukum empiris, sifat penelitian bersifat deskriptif, bentuk data kualitatif, sumber data primer (berupa observasi dan wawancara) serta data sekunder (berupa bahan hukum primer, sekunder, dan tersier). Pengumpulan data menggunakan metode observasi, wawancara, studi kepustakaan. Penentuan informan penelitian menggunakan teknik probability sampling, instrument penelitian mengunakan pedoman wawancara dilengkapi dengan mobile phone, camera digital, pencatatan. Analisis data dilakukan secara deskriptif kualitatif.

\section{PEMBAHASAN}

\section{Pengaturan Terhadap Syahnya Pengangkatan Anak Menurut Hukum Adat dan Agama Hindu di Bali}

Pengangkatan anak di Indonesia merupakan bagian dari kebutuhan masyarakat juga menjadi bagian dari sistem hukum kekeluargaan, disebabkan menyangkut kepentingan baik orang perorang dalam keluarga. Bushar Muhammad, dalam pendapatnya pengangkatan anak dapat dibagi kedalam dua, yakni: adopsi langsung (mengangkat anak), dan adopsi tidak langsung (melalui perkawinan).

Undang-Undang Nomor 23 Tahun 2002 Tentang Perlindungan Anak secara tegas menyatakan bahwa tujuan pengangkatan anak, motivasi pengangkatan anak hanya dapat dilakukan untuk kepentingan terbaik bagi anak dan dilakukan berdasarkan adat kebiasaan setempat dan ketentuan peraturan perundangundangan yang berlaku. Mengenai syahnya pengangkatan anak di Indonesia tentunya harus memenuhi syaratsyarat yang telah diatur berdasarkan adat kebiasaan setempat dan ketentuan peraturan perundangundangan yang berlaku. Syarat pengangkatan anak dibedakan menjadi dua, yaitu syarat untuk anak yang akan diangkat dan syarat untuk calon orang tua angkat, hal tersebut diatur dalam Pasal 12 dan Pasal 13 dalam Peraturan Pemerintah Republik Indonesia Nomor 54 Tahun 2007 Tentang Pelaksanaan Pengangkatan Anak.

1. Pasal 12 ayat (1), syarat anak yang akan diangkat meliputi:

a. Belum berusia 18 (delapan belas) tahun;

b. Merupakan anak terlantar atau diterlantarkan;

c. Berada dalam asuhan keluarga atau dalam lembaga pengasuhan anak dan

d. Memerlukan perlindungan khusus

2. Sedangkan menurut Pasal 13 calon orang tua angkat harus memenuhi syarat-syarat:

a. Sehat jasmani dan rohani;

b. Berumur paling rendah 30 (tiga puluh) tahun dan paling tinggi 55 (lima puluh lima) tahun;

c. Beragama sama dengan agama calon anak angkat;

d. Berkelakuan baik dan tidak pernah dihukum karena melakukan tindak kejahatan;

e. Berstatus menikah paling singkat 5 (lima) tahun;

f. Tidak merupakan pasangan sejenis;

g. Tidak atau belum mempunyai anak atau hanya memiliki satu orang anak;

h. Dalam keadaan mampu ekonomi dan sosial; 
Harmonisasi Hukum Pengangkatan Anak Dalam Desa Adat Di Bali (Suatu Kajian

i. Memperoleh persetujuan anak dan izin tertulis orang tua dan wali anak;

j. Membuat pernyataan tertulis bahwa pengangkatan anak adalah demi kepentingan terbaik bagi anak, kesejahteraan dan perlindungan anak;

k. Adanya laporan sosial dari pekerja sosial setempat;

I. Telah mengasuh calon anak angkat paling singkat 6 (enam) bulan, sejak izin pengasuhan diberikan; dan

m. Memperoleh izin Menteri dan/atau kepala instansi sosial.

Melihat hal tersebut diatas mengenai pengaturan terhadap pengangkatan anak di Bali, mengacu pada teori pluralisme hukum dari Griffiths bahwa di Bali dalam pengangkatan anak terdapat adanya lebih dari satu tatanan hukum dalam suatu arena sosial " by legal pluralism'l mean the presence in a social field of more than one legal order" Mulai dari Undang-undang Nasional, Hukum Adat dan Hukum Agama Hindu.

1. Syahnya Pengangkatan Anak Menurut Peraturan Perundangundangan di Indonesia.

Sahnya pengangkatan anak menurut hukum nasional diatur melalui beberapa dasar hukum dalam bentuk peraturan perundang-undangan yang bertujuan untuk melindungi dan mensejahterakan anak, dimana pengangkatan anak menjadi salah satu pokok perhatian

a. Didahului oleh UU No 4 Tahun 1979 tentang kesejahteraan anak dalam pasal 2, pasal 3, pasal 4 ayat (1), pasal 5 ayat (1) ayat (2) dan ayat (8) dan juga pasal 12 menyinggung tentang pengangkatan anak. Dalam pasal itu ditentukan bahwa pengangkatan anak dilakukan menurut adat dan kebiasaan dengan mengutamakan kepentingan anak untuk kepentingan kesejahteraan anak dan pengangkatan anak yang dilakukan diluar adat dan kebiasaan, dilaksanakan berdasarkan peraturan perundangundangan.

b. UU No.23 tahun 2002 Tentang Perlindungan Anak yang telah di amandemen dengan UU No 35 tahun 2014 Tentang Perlindungan Anak. Pada Bab VIII, khususnya pada pasal 39 sampai dengan pasal 41 undang-undang tersebut memuat ketentuan tentang pengangkatan anak.

c. Untuk melaksanakan ketentuan mengenai pengangkatan anak di dalam UU No.23 tahun 2002, maka pemerintah menerbitkan peraturan pemerintah No. 54 tahun 2007 Tentang Pelaksanaan Pengangkatan Anak dimana syarat-syarat pengangkatan anak diatur pada Bab III pada pasal 12 sampai dengan pasal 18, sedangkan tata cara pengangkatan anak diatur pada Bab IV dari pasal 19 sampai dengan pasal 25.

d. Peraturan Menteri Sosial Republik Indonesia Nomor: 110 /Huk /2009 Tentang Persyaratan Pengangkatan Anak. Persyaratan pengangkatan anak seperti diatur dalam Pasal 7 sampai dengan Pasal 8 yang meliputi:

1. Persyaratan administrasi.

2. Persyaratan ekonomi.

3. Persyaratan kesehatan.

e. Peraturan Jenderal Rehabilitasi Sosial Nomor 02 Tahun 2012 tentang Pedoman Teknis Prosedur Pengangkatan Anak.

Secara legal agar dikatakan sahnya, suatu pengangkatan anak menurut hukum nasional selain melalui proses aturan dasar hukum peraturan perundang-undangan seperti dijelaskan diatas, maka dalam pengangkatan anak yang legal atau sah perlu dikuatkan dengan keputusan Pengadilan Negeri yang mempunyai kepastian hukum yang tetap, keadilan 
hukum, legalitas hukum, dan dokumen hukum.

2. Syahnya Pengangkatan Anak Menurut Hukum Adat Bali

pelaksanaan pengangkatan anak dalam sudut pandang hukum adat Bali dapat dilihat dari Tujuan serta motif atau alasan dilakukannya pengangkatan anak. Pada masyarakat adat Bali bagi seorang yang tidak mempunyai anak akan berusaha mengangkat anak dengan alasan antara lain:

a. Tidak mempunyai anak atau keturunan.

b. Alasan kepercayaan bahwa dengan mengangkat anak akan dapat melahirkan anak kandung sendiri.

c. Meneruskan keturunan yang berkaitan dengan yadnya.

Melihat penjelasan diatas bahwa memang sangat pentingnya memiliki keturunan dalam menjalankan kehidupan baik itu dalam tanggung jawab keluarga maupun masyarakat, apalagi sistem kekerabatan yang kuat dan hubungan religius magis terhadap para leluhur yang sangat dipegang teguh oleh masyarakat adat Bali, menghendaki bahwa kehadiran keturunan adalah suatu hal yang tidak dapat ditawar-tawar lagi keberadaannya dalam menjalankan kehidupan desa adat di Bali.

Dengan demikian tampak jelas bahwa salah satu tujuan dari hidup rumah tangga ialah melahirkan keturunan. Faktanya tidak semua perkawinan mencapai tujuan seperti yang diharapkan, di Bali pasangan suami istri yang tidak memiliki keturunan umumnya mengantisipasinya dengan jalan mengangkat anak.

Pengangkatan anak menurut hukum adat bali adalah secara umum anak yang diangkat berasal dari garis purusha sesuai dengan sistem kekeluargaan yang dianut di Bali yaitu sistem kekeluargaan patrilineal, dimana pengangkatan anak dilakukan untuk melanjutkan keturunan dan sekaligus melanjutkan tanggung jawab baik itu berupa hak maupun kewajiban terhadap keluarga dan tanggung jawab kepada masyarakat (desa adat).

Pengangkatan anak dalam hukum adat Bali selain diatur melalui awig-awig juga diatur dalam hukum hindu yaitu dalam kitab suci wedha yaitu Manawadharmasastra IX, 141, 142, 138, Adiparwa 74 dan 38 yang menjelaskan secara garis besar bahwa selain mempunyai anak sendiri sesorang dapat melakukan adopsi (pengangkatan anak laki) yang padanya berhak mewaris, namun ia berhak mewaris bila ayah angkatnya tidak mempunyai anak laki-laki serta anak angkat tersebut tidak boleh lagi memakai nama keluarga asal dan hak mewarisnya hapus dari keluarga asalnya karena sejak diadopsi ia berhak mewaris kepada keluarga yang mengangkat anaknya.

Tata cara proses pengangkatan anak menurut agama Hindu dan hukum adat Bali, meliputi beberapa kegiatan, seperti:

a. Pasobyahan atau pengumuman dalam paruman atau rapat banjar adat atau desa pakraman.

b. Pelaksanaan upacara widhi widana atau upacara pemerasan sesuai dengan agama Hindu, disaksikan oleh keluarga serta prajuru desa (fungsionaris adat). Pada tahap ini (sesudah pelaksanaan upacara pemerasan) pengangkatan anak dikatakan sah menurut hukum adat Bali. Itulah sebabnya anak angkat itu dikenal dengan sebutan sentana peperasan.

c. Tahap penyelesaian administrasi keberadaan anak angkat, sesudah roses pengangkatan anak menurut agama Hindu dan hukum adat Bali selesai dilaksanakan, dilanjutkan dengan beberapa kegiatan seperti permohonan akta kelahiran bagi 
Harmonisasi Hukum Pengangkatan Anak Dalam Desa Adat Di Bali (Suatu Kajian

anak angkat pada Kantor Kependudukan dan Catatan Sipil Kabupaten/Kota, dll.

Dari penjelasan diatas dapat disimpulkan tata cara pengangkatan anak menurut hukum adat di Bali baru dapat dikatakan sah setelah melewati beberapa tahap, yaitu:

a. Tahap persiapan pengangkatan anak seperti dokumen pribadi, Kartu Keluarga, KTP, Surat Nikah atau Akta Nikah, dan Akta Kelahiran calon anak angkat yang mencantumkan nama orang tua kandungnya.

2) Tahap penyelesaian persyaratan administrasi pengangkatan anak sesuai dengan aturan perundangundang yang berlaku. Dokumen yang sudah lengkap kemudian diserahkan kepada Dinas Sosial untuk selanjutnya dilakukan uji kelayakan orang tua angkat. Jika calon orang tua angkat dinilai layak untuk melakukan pengangkatan anak, maka Dinas Sosial akan mengeluarkan Surat ljin Pengasuhan Sementara bagi calon orang tua angkat selama 6 bulan. Jika selama 6 bulan, calon orang tua angkat dinilai layak untuk dijadikan orang tua angkat, maka Dinas Sosial dapat mengeluarkan rekomendasi untuk hal tersebut.

3) Tahap penyelesaian proses pengangkatan anak menurut hukum Hindu, hukum adat Bali, dan hukum nasional melalui peraturan dan penetapan pengadilan.

4) Tahap penyelesaian administrasi keberadaan anak angkat, sesudah proses pengangkatan anak menurut agama Hindu dan hukum adat Bali selesai dilaksanakan, dilanjutkan dengan beberapa kegiatan seperti permohonan penetapan pengadilan, permohonan akta kelahiran bagi anak angkat pada Kantor Kependudukan dan Catatan Sipil Kabupaten/Kota, dll.
3. Syahnya Pengangkatan Anak Menurut Hukum Agama Hindu

Pengangkatan anak menurut hukum hindu dijelaskan dalam kitab suci Wedha yaitu Manawadharmasastra IX.141, Manawadharmasastra IX.142, Manawadharmasastra IX.138, Adiparwa 74 dan 38 yang menjelaskan secara garis besar bahwa selain mempunyai anak sendiri sesorang dapat melakukan adopsi (pengangkatan anak laki) yang padanya berhak mewaris, namun ia berhak mewaris bila ayah angkatnya tidak mempunyai anak laki-laki serta anak angkat tersebut tidak boleh lagi memakai nama keluarga asal dan hak mewarisnya hapus dari keluarga asalnya karena sejak diadopsi ia berhak mewaris kepada keluarga yang mengangkat anaknya.

Hukum adat Bali yang dijiwai oleh ajaran agama Hindu merupakan sebagai kewajiban (swadharma) dan hak, baik dengan hubungan dengan parahyangan, pawongan maupun palemahan. Kedudukan anak angkat dalam agama Hindu, tidak berbeda dengan anak kandung. Manawadharma Sastra IX.141 menyebutkan bahwa jika anak laki yang mempunyai anak angkat laki-laki yang mempunyai sifat-sifat mulia yang sama akan mewarisi walaupun lahir dari keluarga yang lain.

Pentingnya keturunan dalam hukum Hindu dalam pembahasan permasalahan ini yaitu mengenai pengangkatan anak menurut hukum Hindu. Menurut W.J.S. Poerwadarminta menyebutkan "keturunan adalah anak cucu". Selanjutnya menurut (R. Soetojo Prawironamidjojo, 1979, hlm 150) "keturunan adalah anak yang dilahirkan ".

(Bushar Muhammad, 1983, hlm 11) menyebutkan: "Oleh orang tua, anak itu dilihat sebagai penerus generasinya, juga dipandang sebagai 
wadah di mana semua harapan orang tuanya di kelak kemudian hari wajib ditumpahkan, pula dipandang sebagai pelindungan orang tuanya kelak bila orang tua sudah tidak mampu lagi secara fisik untuk mencari nafkah sendiri".

mengenai jenis anak angkat yang termasuk kedalam kelompok kelurga dan berhak mewaris dijelaskan pada Manawadharmasastra IX.168 disebut Anak Datrima atau anak angkat, yaitu anak yang lahir dari perkawinan sederajat yang oleh ayahnya atau ibunya memberikan dengan penuh kasih sayang sebagai penyerahan air pada waktu-waktu yang susah sebagai anaknya, dan Manawadharmasastra IX.169 disebutkan Anak Krtrima atau anak buatan yaitu anak yang lahir dari perkawinan yang tidak sederajat yang diangkat sebagai anak dalam hubungan dengan melakukan hak kewajiban sraddha dan sakramen kepada orang tua angkatnya.

Sah pengangkatan anak menurut hukum Hindu dapat dilihat pengaplikasian dalam proses pengangatan anak dalam hukum adat Bali yang dijalankan sesuai dengan awig-awig desa adat masing-masing namun secara intinya prosesnya sama, karena pengangkatan anak menurut hukum adat Bali berlandaskan atau bernafaskan hukum Hindu

\section{Proses Pelaksanaan Pengangkatan Anak Pada Desa Adat Di Bali Dikaji Dari Sudut Pandang Plurarisme Hukum \\ Proses \\ pelaksanaan}

pengangkatan anak pada desa adat di Bali merupakan bukti terhadap penerapan dari harmonisasi hukum hal tersebut didalam pelaksanaannya terdapat pluralisme hukum yaitu antara 3 aturan dasar hukum antara lain hukum nasional (undang-undang), hukum adat (awig-awig), dan hukum agama (hukum Hindu).
Sudut pandang pluralisme hukum terhadap pengangkatan anak di desa adat di Bali. akan memuat terjadinya harmonisasi hukum (keselarasan, kecocokan, keserasian, dan keseimbangan) yang saling berdampingan antara ketiga unsur hukum tersebut yang hidup dan tumbuh dimasyarakat (living law) yang berlangsung dalam masyarakat adat di Bali sebagai dasar hukum acuan dalam menjawab persoalan hukum mengenai "Proses Pelaksanaan Pengangkatan Anak pada desa Adat di Bali dari Sudut Pandang Pluralisme Hukum" yang akan menghasilkan kepastian hukum, keadilan, dan kemanfaatan.

Hukum merupakan bagian dari perangkat kerja sebagai sistem sosial untuk mengintegrasikan kepentingan masyarakat sehingga tercipta suatu keadaan yang tertib, dengan demikian hukum melakukan tugasnya dalam menentukan prosedur yang harus dilaksanakan.

Menski memberikan pemahaman mengenai pentingnya pluralisme hukum untuk memahami hukum dan tertib hukum, hukum di kaji tidak hanya mengkaji norma-norma saja, melainkan juga harus mempertimbangkan nilai-nilai, fakta, makna, proses, struktur, hubungan kekuasaan, personel, dan teknologi. Pluralisme hukum mengembangkan model hukum interaktif antara hukum negara, nilai-nilai/etika/agama dan norma-norma sosio-kultural. Model pluralisme hukum mengedepankan kecairan hukum.

Dari penjelasan diatas menjadikan pluralisme hukum sangat membantu memberikan penjelasan terhadap kenyataan adanya keteraturan hukum (legal order) yang diproduksi negara. Dalam konteks ini, pluralisme hukum merupakan konsep yang menujukkan kondisi, bahwa lebih dari satu sistem hukum yang ada dan 
Harmonisasi Hukum Pengangkatan Anak Dalam Desa Adat Di Bali (Suatu Kajian

berlaku bersamaan atau berinteraksi dalam mengatur berbagai aktivitas dan hubungan manusia di suatu tempat, dari hal tersebut dapat ditarik bahwa ada tiga jalan dalam memahami pluralisme hukum antara lain pertama pluralisme hukum menjelaskan relasi berbagai sistem hukum yang bekerja dalam masyarakat. Kedua, pluralisme hukum memetakan berbagai hukum yang ada dalam suatu bidang sosial. Ketiga, menjelaskan relasi, adaptasi, dan kompetisi antar sistem hukum. Ketiga hal tersebut membuat pluralisme hukum memperlihatkan pilihan warga memanfaatkan hukum tertentu ketika berkonflik.

Proses Tata cara pengangkatan anak menurut hukum adat Bali, yang bernafaskan ajaran agama Hindu dan tetap berpedoman dengan undangundang nasional yang mengatur terhadap pengangkatan anak di Indonesia meliputi beberapa kegiatan, seperti:

d. Pasobyahan atau pengumuman dalam paruman atau rapat banjar adat atau desa pakraman.

e. Pelaksanaan upacara widhi widana atau upacara pemerasan sesuai dengan agama Hindu, disaksikan oleh keluarga serta prajuru desa (fungsionaris adat). Pada tahap ini (sesudah pelaksanaan upacara pemerasan) pengangkatan anak dikatakan sah menurut hukum adat Bali. Itulah sebabnya anak angkat itu dikenal dengan sebutan sentana peperasan.

f. Tahap

penyelesaian administrasi keberadaan anak angkat, sesudah proses pengangkatan anak menurut agama Hindu dan hukum adat Bali selesai dilaksanakan, dilanjutkan dengan beberapa kegiatan seperti permohonan akta kelahiran bagi anak angkat pada Kantor Kependudukan dan Catatan Sipil Kabupaten/Kota, dll. (Wayan P. Windia., I Gede Pasek Pramana 2018, hlm. 208).
Dari penjelasan diatas dapat disimpulkan proses tata cara terhadap pengangkatan apabila dilihat dalam sudut pandang plurarisme hukumnya melewati beberapa tahap, yaitu:

a. Tahap persiapan pengangkatan anak seperti dokumen pribadi, Kartu Keluarga, KTP, Surat Nikah atau Akta Nikah, dan Akta Kelahiran calon anak angkat yang mencantumkan nama orang tua kandungnya.

b. Tahap penyelesaian persyaratan administrasi pengangkatan anak sesuai dengan aturan perundangundang yang berlaku. Dokumen yang sudah lengkap kemudian diserahkan kepada Dinas Sosial untuk selanjutnya dilakukan uji kelayakan orang tua angkat. Jika calon orang tua angkat dinilai layak untuk melakukan pengangkatan anak, maka Dinas Sosial akan mengeluarkan Surat ljin Pengasuhan Sementara bagi calon orang tua angkat selama 6 bulan. Jika selama 6 bulan, calon orang tua angkat dinilai layak untuk dijadikan orang tua angkat, maka Dinas Sosial dapat mengeluarkan rekomendasi untuk hal tersebut.

c. Tahap penyelesaian proses pengangkatan anak menurut hukum Hindu, hukum adat Bali, dan hukum nasional melalui peraturan dan penetapan pengadilan.

d. Tahap penyelesaian administrasi keberadaan anak angkat, sesudah proses pengangkatan anak menurut agama Hindu dan hukum adat Bali selesai dilaksanakan, dilanjutkan dengan beberapa kegiatan seperti permohonan penetapan pengadilan, permohonan akta kelahiran bagi anak angkat pada Kantor Kependudukan dan Catatan Sipil Kabupaten/Kota, dll.

Harmonsasi hukum yang terdapat dalam pelaksanaan pengangkatan anak pada desa adat di Bali diatur mulai dari peraturan hukum 
perundang-undangan antara lain adalah Undang-Undang No 4 Tahun 1979 Tentang Kesejahteraan Anak dalam pasal 2, pasal 3 , pasal 4 ayat (1), pasal 5 ayat (1) ayat (2) dan ayat (8) dan juga pasal 12 yang menyinggung tentang pengangkatan anak. Dalam pasal tersebut ditentukan pengangkatan anak dilakukan menurut adat dan kebiasaan dengan mengutamakan kepentingan anak, kepentingan kesejahteraan anak dan pengangkatan anak yang dilakukan diluar adat dan kebiasaan, dilaksanakan berdasarkan peraturan perundang-undangan.

Kedua Undang-Undang Nomor 35 Tahun 2014 Tentang Perlindungan Anak Pasal 39 ayat (1) Pengangkatan Anak hanya dapat dilakukan untuk kepentingan yang terbaik bagi Anak dan dilakukan berdasarkan adat kebiasaan setempat dan ketentuan peraturan perundang-undangan.

Ketiga Peraturan Pemerintah No.

54 Tahun 2007 Tentang Pelaksanaan Pengangkatan Anak Bagian Pertama Pengangkatan Anak Antar Warga Negara Indonesia Pasal 8 Pengangkatan anak antar Warga Negara Indonesia sebagaimana dimaksud dalam Pasal 7 huruf a meliputi:

a. Pengangkatan anak berdasarkan adat kebiasaan setempat; dan

b. Pengangkatan anak berdasarkan peraturan perundang-undangan.

Keempat, Hal yang sama juga diatur pada Pasal 10 ayat 1 Peraturan Menteri Sosial Republik Indonesia Nomor: 110 /Huk /2009 Tentang Persyaratan Pengangkatan Anak yang berbunyi Pengangkatan Anak antar Warga Negara Indonesia sebagaimana dimaksud dalam Pasal 9 huruf a, meliputi:
a. Pengangkatan Anak berdasarkan adat kebiasaan setempat; atau
b. Pengangkatan Anak berdasarkan peraturan perundang undangan.

Selanjutnya juga Peraturan Menteri Sosial Republik Indonesia Nomor: 110 /Huk /2009 Tentang Persyaratan Pengangkatan Anak. Persyaratan pengangkatan anak seperti diatur dalam Pasal 7 sampai dengan Pasal 8 yang meliputi:
a. Persyaratan administrasi.
b. Persyaratan ekonomi.
c. Persyaratan kesehatan.

Empat dasar aturan ini membuktikan bahwa aturan hukum nasional dengan hukum adat (awigawig desa adat di Bali secara umum). tidak bertentangan satu sama lainnya karena syarat dan tata cara dalam proses pengangkatan anak dilakukan sesuai dengan menurut adat dan kebiasaan dengan mengutamakan kepentingan anak dan kepentingan kesejahteraan anak dengan memenuhi terlebih dahulu syarat-syarat baik itu persyaratan administrasi, persyaratan ekonomi, dan persyaratan kesehatan dari keluarga yang mengangkat, proses ini terjadi dan dibicarakan terlebih dahulu pada rembug keluarga kecil (suami istri), kemudian baru rembug keluarga yang lebih besar (tugelan atau saudara kandung suami), dengan tujuan yang sama antara lain untuk memastikan anak yang akan diangkat, agama, tata cara pengangkatan anak, dan memenuhi persyaratan-persyaratan yang telah ditentukan oleh peraturan perundangundangan.

\section{PENUTUP}

Syahnya pengangkatan anak dapat dilihat dari 3 dasar hukum yaitu hukum nasional, hukum adat, dan hukum agama. Hukum nasional maulai dari Undang-undang No 4 Tahun 1979 Tentang Kesejahteraan Anak, UU No.23 tahun 2002 Tentang Perlindungan Anak yang telah di amandemen dengan UU No 35 tahun 2014 Tentang Perlindungan Anak, Peraturan Pemerintah No. 54 tahun 
Harmonisasi Hukum Pengangkatan Anak Dalam Desa Adat Di Bali (Suatu Kajian Pluralisme Hukum) (NK. Kantriani \& IBS.Putra., 172-182)

2007 Tentang Pelaksanaan Pengangkatan Anak, Peraturan Menteri Sosial Republik Indonesia Nomor: 110 /Huk /2009 Tentang Persyaratan Pengangkatan Anak, Peraturan Jenderal Rehabilitasi Sosial Nomor 02 Tahun 2012 tentang Pedoman Teknis Prosedur Pengangkatan Anak. Khususnya hukum adat di Bali secara umum pengangkatan anak tidak bias terlepas dari aturan adat Bali yang lebih banyak bernafaskan ajaran agama Hindu.

Proses pelaksanaan pengangkatan anak pada desa adat di Bali, dari sudut pandang pluralisme hukum yaitu adanya perpaduan antara 3 aturan dasar hukum antara lain hukum nasional (undang-undang), hukum adat (awig-awig dan pararem), dan hukum agama (hukum Hindu), dimana ketiga dasar hukum tersebut berjalan secara bersamaan dalam pelaksanaan pengangkatan anak secara selaras serasi, dan seimbangan, sehingga terciptanya suatu kerharmonisasian hukum dalam pelaksanaan pengangkatan anak pada desa adat di Bali.

\section{DAFTAR PUSTAKA}

John Griffiths. 1986, "What is Legal Pluralism?", Journal of Legal Pluralism and Unofficial Law, number 24, ISSN 0732-9113.

Kamil Ahmad dan M Fauzan. 2010, Hukum Perlindungan dan Pengangkatan Anak di Indonesia. Jakarta: PT. Raja Grafindo.

Menski, Werner. (2008). Perbandingan Hukum dalam Konteks Global, Sistem Eropa, Asia, dan Afrika. Nusa Media, Bandung.
Mudaris Zaini. 1992, Adopsi Suatu Tinjauan Dari Tiga Sistem Hukum, Sinar Grafika, Jakarta.

Muhammad Bushar. 1981, PokokPokok Hukum Adat. Jakarta: Pradnya Paramita.

Prawirohamidjojo, R. Soetojo dan Asis Safioedin. (1979). Hukum Orang dan Keluarga. Bandung: Alumni.

Soekanto Soerjono. 2012, Kesadaran Hukum dan Kepatuhan Hukum, (Jakarta: Rajawali Press,).

Wignjodipuro Soerojo. 1967, Pengantar dan Asas-asas Hukum Adat, Jakarta, CV Haji Masagung.

Windia, Wayan P dan Ketut Sudantra. (2006). Pengantar Hukum Adat Bali, Lembaga Dokumentasi dan Publikasi Fakultas Hukum Universitas Udayana, Denpasar.

Windia, Wayan P. (2009). Perkawinan Pada Gelahang. Udayana Unversity Press, Denpasar. 